\title{
Research on 6S Management Mode of Students in Vocational Colleges from the Perspective of College- enterprise Cooperation for Talents Training*
}

\author{
Weinan Pan \\ Scientific Research and Development Planning Department \\ Hunan Food and Drug Vocational College \\ Changsha, China
}

\author{
Shuixiu Deng** \\ College of Pharmacy \\ Hunan Food and Drug Vocational College \\ Changsha, China \\ **Corresponding Author
}

\begin{abstract}
College-enterprise cooperation for talents training is an inevitable trend and also a beneficial education practice integrating both the supply and demand sides-the education circle and the industrial circle. Strengthening student management is an effective way to improve teaching management level and facilitate the realization of talent training goal for vocational colleges. For vocational colleges, deepening industry-education integration, strengthening college-enterprise cooperation and effectively taking the resource advantages of advanced enterprises are conducive to achieving ideal results in student management. From the perspective of college-enterprise cooperation for talents training, this paper explores the feasibility and ways for implementing the enterprise management $6 \mathrm{~S}$ management mode in vocational colleges, aiming to provide ideas and reference experience for vocational colleges to achieve efficient student management goal in collegeenterprise cooperation.
\end{abstract}

Keywords-college-enterprise cooperation; talents co-training; vocational college; students management; 6s management mode

\section{INTRODUCTION}

General Secretary Xi Jinping pointed out clearly in the reports of the 19th National Congress of the Communist Party of China: improve vocational education and training system, deepen industry-education integration and college-enterprise cooperation. Recently, the General Office of the State Council issued the Several Opinions on Deepening Integration of Industries into Education which clarifies the working direction, aims and tasks in deepening modern vocational education reform and making use of the leading role of enterprises to develop high quality creative talents and technical and skilled talents.

*Project Fund: This paper is the achievement of the educating and teaching reform of vocational colleges research project of Hunan Province: Research on 6S Management Mode of Students in Vocational Colleges from the Perspective of College-Enterprise Cooperation (Project No.:

ZJGB2016301) and 2017 key subject of Hunan Association of Education Researchers: Research on 6S Management Mode of Students in Secondary Vocational Colleges from the Perspective of College-Enterprise Cooperation for Talents Co-Training (No.: XJK17A003), and funded by 2016 Hunan Development Program of Young Teachers of Regular Institutions of Higher Education (No.:2016078).
The most important purpose for vocational colleges to deepen industry-education integration and strengthen collegeenterprise cooperation is, by establishing talent training platforms, to promote social practice ability of the talents and strengthen students' future professional competitiveness. However, there is little research on realization of $6 \mathrm{~S}$ management of students from the perspective of collegeenterprise cooperation for talents co-training, so this paper, from this perspective, explores the effective ways for vocational colleges to realize $6 \mathrm{~S}$ management of students during college-enterprise cooperation.

\section{OVERVIEW OF 6S MANAGEMENT MODE}

6S refers to six items SEIRI (Sort), SEITON (Set in Order), SEISO (Shine), SEIKETSU (Standardize), SHITSUKE (Sustain) and SECURITY (Security). As all six Japanese words start with "S", hence the name 6S management. Derived from $5 \mathrm{~S}$ of the Japanese enterprise, $6 \mathrm{~S}$ management is an effective method for management of modern enterprises, and its main purpose is to improve efficiency, ensure quality and make the workplace neat, in order and safe [1]. Applying the $6 \mathrm{~S}$ management mode in the management of students in vocational colleges is expected to sort and set students' learning atmosphere and disciplines in order, shine and standardize students' thoughts and emotions, develop and improve students' comprehensive quality, as well as ensuring students' safety. In the practice of college-enterprise cooperation for talent co-training, to realize the ideal goal of students management by using $6 \mathrm{~S}$ management mode, vocational colleges is supposed to deepen college-enterprise cooperation, fully realize the important leading role the enterprises play in students management, as well as actively exploring the information-based and intelligent students management mode so as to further improve the efficiency of students management.

\section{FEASIBILITY OF 6S MANAGEMENT IN VOCATIONAL COLLEGES IN COLLEGE-ENTERPRISE COOPERATION}

To realize effective management of students, vocational colleges not only need professional teaching faculty, but also have to use certain auxiliary teaching measures. For example, 
to manage the learning style of students, they need to have a strict team of teachers to carry out routine inspection and supervision of learning style to find problems and correct problems timely so as to regulate learning style and disciplines. For developing students' comprehensive quality, the colleges are required not only to impart professional theoretical knowledge to students, but also to provide students with a practical training platform to apply the knowledge they obtained to consolidate what they have learned. Establishing cooperation relationship with enterprises is an effective way to provide such practice opportunities for students. Relevant rules and regulations of the enterprise require students to correct attitude and observe strictly disciplines to some extent, which can play a effective role in managing and constraining the students, and moreover, the professionals and technical personnel can also lead and guide students to a certain extent to improve comprehensive quality, master more communication skills and job skills, which can further help vocational colleges to improve the efficiency in students management.

At present, vocational colleges are actively exploring the modes and approaches of industry-education integration, college-enterprise cooperation and collaborative education. The combination of college education and enterprise training has played a double security role in the management and training of talents, and also can continuously improve students' social practice ability and comprehensive vocational quality. In addition, this process can also help vocational colleges to achieve their goal in student management. Many foreign countries have been exploring the application of $6 \mathrm{~S}$ management mode in student management, which also provides experience and useful reference for vocational colleges to perform well in student management from the perspective of college-enterprise cooperation.

\section{WAYS TO IMPLEMENT 6S MANAGEMENT MODE IN VOCATIONAL COLLEGES IN COLLEGE-ENTERPRISE COOPERATION}

\section{A. Rectifying Learning Style to Shine Thoughts of Students}

At present, facing the fierce competition in the talent market, vocational colleges have to focus on the overall situation of developing high-quality technical and skilled talents and emphasize management of learning style in student management. Vocational colleges should attach great importance to construction of learning style, take advantages of college-enterprise cooperation and communication and insist on putting students first to meet their studying needs. Besides, based on the standardized management and strict requirements, vocational students shall build studying platforms and create learning environment and working conditions conducive to helping students obtain professional knowledge and strengthening the practical skills and innovation awareness, so as to create good atmosphere for students' improvement academically and vocationally.

In the meantime, enterprises can help colleges establish learning and employment guidance platforms, optimize the education mechanism and deepen the integration of teaching and educating; through class mentor and program tutor, strengthen professional leading, academic guidance and practices to help students solve problems about academic promotion and vocational development, to gradually improve students' cognition in professional learning and development, develop their practice application ability and let them realize that they study hard for the purpose of a better development not for other purposes, so that they can correct their learning style and attitude, become active in studying and remove unhealthy thought and negative emotions in study, so as to create good academic atmosphere characterized by conscious learning and independent exploration among students in vocational colleges [2].

\section{B. Conducting In-depth Cooperation to Improve Comprehensive Quality of Students}

In the college-enterprise cooperation, vocational colleges should pay attention to collaborative education so as to improve the comprehensive quality of talents. Insisting on college management principle "profession follows the industry; teaching follows production", vocational colleges shall actively serve the regional economic and social development, cooperate with high-quality enterprises, construct a talent training platform based on college-enterprise cooperation and take advantages of the experience and resources of advanced enterprises in college-enterprise cooperation to keep pace with the times and promote education innovation to inject momentum to the characteristic development of the vocational colleges. Moreover, both the colleges and enterprises shall actively communicate with each other and exert their own advantages to integrate high-quality resources so as to improve talent training quality to provide more creative and comprehensive high-quality technical and skilled talents.

Based on cooperation, enterprises and vocational colleges can jointly establish featured departments, majors and classes to provide one-stop solutions for vocational education and promote talent training to develop towards socialization, pragmaticism and specialization, which is a significant action to effectively implement the Decision of the State Council on Accelerating the Development of Modern Vocational Education and drive regional education and economy development. During the college-enterprise cooperation, vocational colleges should, centering on the needs of economic and social development for talents, actively explore and continuously innovate education and teaching contents, talent training scheme and other aspects; and in the meantime, enterprises should also amend talent training schemes according to actual needs of the vocational colleges, give full support to them in establishment of practice base and featured class and guide the vocational colleges to train talents based on Industry needs to future improve the degree of fit-to-purpose and accuracy of vocational education and the industry's needs for talents.

Vocational colleges can make full use of the superior resources such as college-enterprise cooperation and united training to encourage and guide students to learn and develop independently. The experimental base, talent training base, IOS training base and industry-education integration and innovation base, etc. jointly established by colleges and enterprises construct a talent training mode of "combination of 
learning with working" to provide more practical training opportunities for vocational college students to improve their professional skills and vocational quality [3]. In the meantime, the college-enterprise cooperation can give full play to the teaching resources, employment service and other advantages, promote the deep docking of talent training of colleges and vocational education and inject new ideas and momentum to more vocational colleges in innovation of education content, teaching methods and management mode, which places an important irreplaceable role in improving comprehensive quality of talents.

\section{Using Intelligent Technology to Realize Safety Goal}

For vocational colleges, safety management is the primary task and the top priority. During college-enterprise cooperation, the vocational colleges can use modern intelligent technology to establish the smart campus and mainly focus on the construction of data center and application platforms of unified identity authentication, public portal and teaching, students, logistics, personnel, OA, etc. to further improve the college' informatization management level and use the informatization to ensure the safety index of talent training. Vocational colleges should collect all kinds of schooling data, then digitize, integrate and manage the data effectively, and use them. Counselors and head teachers can, by analyzing the data of access control system, collect students' information about coming back late to avoid safety accidents caused by coming back late or staying out all night; subject teachers can, by observing the professional curriculum construction data, understand the development of the major in a macroscopic way, find out the vulnerable spot and make corrections in time; the student management department, counselors and class teachers can also understand the family economic status of students by checking the payment data of students, so that they can provide the poverty students with part-time jobs to solve their financial problems on the premise of safety first. To carry out smart campus activities, the colleges should give full play to the advantages of informatization technology and overcome the time and space difficulties in college-enterprise cooperation to realize talent co-training; make full use of informatization technology to consolidate the talent training mechanism and achieve the effect of modeled construction from rules to procedures to standard, further ensure the transformation and implementation of college-enterprise cooperation achievements, so as to realize integrated to collaborative to comprehensive development both in scope and in depth of the construction of smart campus of vocational colleges.

In addition, the vocational colleges can build a collegeenterprise remote interaction video teaching platform to break the site barrier in professional practice teaching and realize diverse professional practice teaching means during the cooperation between colleges and enterprises, through the video two-way remote interaction technology. Fixed and mobile multimedia video interaction acquisition devices, desktop computers, laptop computers, mobile tablet PCs, smart phones etc. can be used as the tools to realize remote interaction video teaching and the real-time connection of class and the enterprise's operation site during the professional practice teaching so as to carry out demonstration teaching and Q\&A interaction. Students can also use mobile phones and other intelligent terminals to learn independently and explore new forms of mobile interchange and professional practice teaching between colleges and enterprises. The collegeenterprise remote interaction video teaching platform can greatly improve the collaborative teaching level of the both sides and realize real-time linkage and two-way teaching and research between the colleges and enterprises as well as carrying out relevant activities. The college-enterprise collaborative teaching mode can create more practice teaching channels for both the colleges and enterprises, and this teaching mode makes technology upgrade less cost, safer and true, fast and convenient, and can further improve the talent training achievement.

At present, some vocational colleges are actively establishing the college-enterprise cooperation comprehensive platform in the informatization environment to support and realize the mechanism management, state tracking and performance assessment of the college-enterprise cooperation to the maximum extent. Based on implementation of collegeenterprise cooperation activities both online and offline, the colleges set up teaching teams, determine teaching objectives, conduct post analysis and formulate training plans, so that the colleges and enterprises can realize collaborative teaching and jointly assessment. In the meantime, with the help of the digital platform, they can digitalize the data of students' actual status. Moreover, the platform can collect the all kinds of coordinated operation data of the college and the enterprise to obtain real-time reflection of working performance to realize early warning decision. In this way, they can effectively improve students' learning and practice security to further improve the efficiency of cooperative education [4].

\section{CONCLUSION}

From the perspective of college-enterprise 6S management, the $6 \mathrm{~S}$ management mode can effectively help vocational colleges with student management to improve the management efficiency. To reach this goal, vocational colleges are required to further deepen cooperation, make reasonable use of resources, seek innovation in management mode, focus on the improvement of students' comprehensive quality to make the students management easier and keep breast with the times.

\section{REFERENCES}

[1] Pan Weinan, Dei Shuixiu, Shu Zhan. Introduction of 6S Management Concept to Building High Quality Servise Platform in Vocational College Library $[\mathrm{J}]$ Journal of Library and Information Sciences in Agriculture, 2014,26(08):165-168.

[2] Cheng Mei, Wu Huiming. Exploration on Enterprise-Style Management of Students in Vocational Colleges- A Case of Chuzhou Vocational \& Technical College Dormitory 6S Management [J]. Journal of Chuzhou Vocational and Technical College, 2007(03):37-39.

[3] Tan Yi. Introduction of "6S" Management Mode in Practice Field for Developing Students' Vocational Quality [J]. Science \& Technology Information (Academic Research), 2008(12):166.

[4] Zhao Xinchun. Study on the Application of 6S Management Mode in Management of Students in Vocational Colleges in the Information Age [J], PC Fan, 2017(05):179. 